\title{
Destination of Cultural Tourism at Pariangan Based Upon Adat Basandi Syarak Syarak Basandi Kitabullah
}

\author{
Khanizar \\ \{khanizar@hum.unand.ac.id \} \\ Universitas Andalas, Padang, Indonesia
}

\begin{abstract}
The destination is a place to visit for a more significant time during somebody's travel compared to the other places passed through during the trip. The discussion is under the Strategy of analysis development of SWOT and is adjusted to the tourism development based upon ABS-SBK, in the Province of West Sumatra. Besides, it may strengthen the national cultural identity and cultural conservation through a development Strategy of the most beautiful area of tourism village across the world at Pariangan Regency of Based upon ABSSBK. Moreover, the purpose of the research would be (1) to map up both strategy and development of Strategy of the most beautiful area of tourism village across the world at Pariangan Regency of Based upon ABS-SBK in West Sumatra Province; (2) to evaluate the enforcement ever done by both formal and informal institutions as well as local to the the development of the tourism area; (3) to define the map of problem, to update the names of local institution ever-existing both etymologically and genealogically; (4) to schedule the research result obtained through website online. Additionally, several other outputs such as nationally and internationally accredited documentary film and scientific article are also accounted for.
\end{abstract}

Keywords: Tourism Destination, Most Beautiful Village, ABS, Koran

\section{INTRODUCTION}

The Nagari of Pariangan Padang in West Sumatra is included in in the list of the most beautiful village across the world released by the Travel Budget in 2012. The Travel Budget welcomed the Village of Pariangan as one of the villages included in the list of world's16 Most Picturesque Villages. Due to such the most beautiful village predicate, the village of Pariangan located at the Regency of Tanah Datar, West Sumatra. Pariangan is the oldest Nagari in Minangkabau and exactly situated on the slope of Mount Marapi, approximately 15 kilometers from the Town of Batusangkar.

Astronomically, NagariPariangan is at $100^{0} \cdot 11^{\prime}-100^{\circ} .19^{\prime}$ east longitude and $0^{0} 25^{\prime}-33^{\prime}$ south latitude. It is on the height \pm ranged $500-850$ of the sea level and its temperature is about $21{ }^{\circ} \mathrm{C}-22{ }^{\circ} \mathrm{C}$ as it is located on the hillsides. Geographically, the Nagari of Pariangan is, 1) southward bordered to KenagarianSialahan, 2) eastward bordered to Sungai Jambu, 3) westward bordered to NagariSabu, 4) and northwards bordered to the Mount Marapi. The position of the most beautiful village at the Regency of Tanah Datar is an inland running to the waist of ridges of mount (Bukit Barisan) reaching the height of 1.500 meters from the sealevel.[1] Prior to comparing to the wonderlands in the European countries and it is found that 
Indonesia preserves the panoramic villages and fine atmosphere, too, based upon budget Travel version. the four other villages are Hamlets of Wengen (Swiss), Eze (Prancis), Niagara on the Lake (Canada Cesky), as well as Krumlov (Czech).

As someone visits this Nagari, s/he would be offered with a beautiful view and culture as well as well maintained buildings until now. We could also found that a better part of the citizens at Pariangan are still using Minangkabause traditional houses called RumahGadang. Many of them are even hundreds of years old. The area extended strategy is needed in order to get rid of the worry that the village will undergo degradation so that the data quality such as the adat itself might be misunderstood or it might extinct sooner that it is expected. the tourism area of the most beautiful across the world of one of the knowledge object embracing the tourism object. Its potency is acknowledged and deserves pride and its historical and cultural values are necessary to be conserved.

In general, this papers is aimed at studying the effort of tourism destination at the Regency of Tanah Datar under the basis of $A B S-S B K$ and to promote the values it contains. The particular purpose (a) to discover the potency of Strengths and weaknesses the Strategy development of for tourism area of the most beautiful village across the world at the Regency of Desa Tanah Datar under the basis of $A B S-S B K$ in Sumatra west. Province (b) to know the development strategy for tourism are of the most beautiful village across the world at the Regency of Tanah Datarunder the basis of $A B S-S B K$ in West Sumatra Province, and (c) to know the Strategy of tourism area development of the most beautiful village across the world at the Regency of Tanah Datar under the basis of ABS-SBK in West Sumatra Province.[2]

Moreover, as it preserves a particular characteristic and uniqueness about the customary in Minangkabau, the tourism area also has a historical link to the most beautiful village across the world at the Tanah Datar regency. The orientation strategy of tourism area development at the most beautiful village across the world at the Tanah Datar Regency under the basis of ABS-SBK in west Sumatra Province has unnecessarily removed the significance of the historical spots of the people separating them from theirs.

\section{RESEARCH METHOD}

This paper supports the method of this research, I also used references related to the strategy of tourism area development the most beautiful village across the world at Pariangan, Regency of Tanah Datar under the basis of ABS-SBK, this study is also supported by the simple matrix approach of S(strength), W(weakness), O(opportunity), and T(threat) (strengths, weaknesses, opportunities, threats) in order to identify strategic alternatives possible to do by the way of (1) to make use of strength and opportunity available, and (2) to improve both the weakness and threat possibly to occur[3][4]. In detail, the combinatorial analysis to identify strength, opportunity, and threats might be mapped up in the matrix of SWOT[3][4].

\section{RESULT AND DISCUSSION}

The Nagari of Pariangan is the oldest one across Minangkabau that up to the moment evidently proved in the literature of the Minangkabau society themselves. "Tradition referred to Pariangan, Kingdom referred to Pagar Ruyung“ (Baradek ka Pariangan Barajo Ka Pagaruyung). Physically, we will even find out more historical evidence such as a traditional house, the traditional mosque (Surau), menhir, inscription and other traditional buildings, grave of Dt TantejoGurhano (long grave), Hall of saruang, Long Hall, Small Hall, Hall of Pasujian and so on. All are the authentic evidence we could find out until now. However, 
unfortunately, many Minangkabause young generations do not know anymore and do not understand them and even the people of the Pariangan themselves. These are due to some factors: a) there is no inheritance of value and education on the adat to the young generation. b) many people of Pariangan migrating due to economic force, c) Lack of both promotion and socialization of the adat itself, d) a gradual erosion of the adat understanding among the sons and the daughters of Nagari resulting that they do not comprehend it and the lack of HRD of the adat holder, e) the stagnancy of adat education of the adat Heads to the younger generation.

Such steps are important,[5] to do to set up a pilot project area for a strategy to develop a tourism area of the most beautiful village across the world at Pariangan, the Regency of Tanah Datar under the basis os ABS-SBK will seriously be made a pilot project for other areas in developing the cultural tourism. When the maintenance of the traditional values is already done and is comprehended based upon the cultural tourism, thus, the economic condition of the people in the area is getting better and the State income from the tourism sector might increase, and the environmental conflict might be avoided. The tourism consciousness level at the most beautiful village across the world in the Regency of Tanah Datar should be fertilized through comprehension of ABS-SBKinMinangkabau. The most beautiful village across the world at The Regency of Tanah Datar truly preserves a very big opportunity to become foreign ritual tourism destination and Minangkabause arranged it in given times albeit it needs a long time and accumulative jobs to realize them. Though it is just a plan, it may be said too late and it needs a long time and the willingness as to create the most beautiful village across the world at Tanah Datar Regency as a tourism destination of foreign tourist already started since long time ago.[2]

As a destination of tourism object of the most beautiful village across the world at the Tanah Datar Regency, certainly, it is proper for sale area and is felt very urgent to realize the program. As to answer the "concern" of the people of the most beautiful village across the world at the Tanah Datar Regency is frequently published in various media, as well as to maintain the area and the building conservation whose condition is saddening. Many parties already tried to find out the best solution for the government, the Governor Head of Legal Region (KDH) Level I West Sumatra Province.

As to realize both conservation and strategy to develop the tourism area of the most beautiful village across the world at the Tanah Datar Regency under the basis of ABS-SBK in west Sumatra province it is necessary to coordinate a political will among the related government service, such as exposed by the Head of Cultural and Tourism Service (KADISBUDPAR) of West Sumatra. One of the important factors necessary to pay attention on in materializing it is the reliable HRD having dependable and professional visions not as used to happen so far that many cases are not the right man on right place handling the world of tourism at the most beautiful village across the world at the Regency of Kabupaten Tanah Datar.[6]

Considering the importance of developing the tourism area of the most beautiful village across the world at the Tanah Datar Regency based upon $A B S-S B K$ in Provence west Sumatra as mentioned above, therefore, the research point will explain how the potency Strengths and Weaknesses for the Strategy of developing tourism area of the most beautiful village across the world at the Tanah Datar Regency based upon ABS-SBK in West Sumatra Province. Moreover, it is necessary to inform and to enlighten the adat and customary to the young generation in Minangkabau. Then, to emphasize the understanding of adat as the strategy ABS-SBK in West Sumatra.[7][8] 
It seems that this step is very important in this research in order to develop the tourism area at the most beautiful village across the world under the basis of ABS-SBK inWest Sumatra. If this is seriously done, it will be a pilot project for the other areas in developing cultural tourism. Whenever the maintenance of the traditional values is already comprehended and conducted in step with the cultural tourism basis, thus, the people's economic condition in the area is getting better and the State income from the tourism sector may increase and the environmental conflict may be minimized and this will be followed by the pilot project of developing and maintaining the cultural values[9].

The strategy of developing tourism is for the most beautiful village across the world at Pariangan, Regency of Tanah Datar under the basis of ABS-SBK was already done in previous research supporting this one, it was on Conservation and Developing Historical Area of Sheikh Burhanuddin's Ulakan Grave Based upon basis Ritual Tourism Industry in Pariaman west Sumatra, a Higher Education Prominent Applied Research (Penelitian Terapan Unggulan Perguruan Tinggi),[10] financed by Ministry of Research and Technology of Higher Education: a ritual tourism industry-based research. The following research was The Character Building of AbandonedChildren in west Sumatra and Mentawai Island: A Culture-Based Research, Higher Education Prominent Applied Research,[10] a care-house based research in west Sumatra. Both pieces of research were very useful to synergize the previous ones with the present research. Besides, the research in my dissertation will also become the strong reference to understand the strategic aspects of cultural events in west Sumatra, it is titled Ceremonial Genealogy of Tabut at Pesisir west Sumatra 2016 in Postgraduate program University of Udayana Denpasar. The other publication of mine was in e-journal of Cultural Studies volume 9, number 3, August 2016, "Genealogy cultural aesthetics of the Sumatran West coastal community" make it an important reference in this research.[11]

The problem of the strategy on developing the tourism area for the most beautiful village across the world at Pariangan, Regency of Tanah Datar based upon ABS-SBK in West Sumatra Province is hope to be accepted under the concepts as stipulated below. The concepts as the form of social and cultural institution are the human's behavior restrictions based upon the common consent becoming a collective consciousness in a social interaction in form of a set of humanly devised constraints on actions; rules of the game and such a concept is a guidance and a rule of conduct for each social member either in individual or social lives. This offers a space (and at the same time the restrictions) which is the field developing the creativity of human potency to yield social, cultural, and economic works and the works of intellectual thoughts as a machine of social development and growth covering the whole aspect of life.

Nowadays, the social participation plays an important role in the advancement of ABSSBK on the basis of cultural tourism, reflecting the partiality to the local people referred to as the owner of both physical and cultural resources they should get involved in planning, executing, and evaluating the society based tourism development. The society based developing conception is done under the bottom-up approach, the society is given both opportunity and role as wide as possible in the development. By doing so, the sustainable development of tourism would come into a reality that could materialize the harmonious balance of sustainable cultural resources, the welfare of the local people, and tourist's satisfaction. A number of world's class organization already stipulated the importance of social participation including Indonesia through Regulation No. 252000 on National Development Program.[10] 
Both the soul and spirit of the International Cultural Charter already adopted the 6 principles in the cultural tradition made use for the sake of tourism seemed much more different from the one's regulation No. 221999 Provincial Autonomy legalized some years ago. Both society involvement and participation in the cultural resources management must be done as early as possible or at the phase of planning, executing, and evaluating[12]. The management of cultural resources should offer both economic profit and benefit to the local people. Moreover, its management must be done sustainability not only for the present generation but also for the one of the future.

Both involvement and role of the society in the development strategy to promote the tourism area of the most beautiful village across the world at Pariangan, the Regency of Kabupaten Tanah Datar based upon ABS-SBK in West Sumatra Province since the phase of planning, executing, and evaluating eventually offering economic profit to the people supporting it. Last but not least, the emphasis of priority to the understanding of cultural heredity as the form of the local wisdom at the local area[13].

The promotion of sustainable tourism, Word Tourism Organization made emphasis on three important factors namely quality, continuity, and balance[14]. The sustainable tourism is expected to be able to offer a quality experience to the tourists, quality of life including historicity to the local people and protection to the environmental quality of resource).[15] [16].

\section{CONCLUSIONS}

The baseline concept prior to the creation of popular based tourism is the sustainable one under three main conditions that should be put into account to make it come about. It has to offer a quality experience for the sake of tourists. Other things that should also be accounted for in the quality improvement of life of the local people and the quality of the sustainable tourism environment should be able to assure the continuity of both cultural and natural resources of the local people as well as the pleasing experience for the tourists. The sustainable tourism has to keep the balance among others the needs of the tourism industry, environmental supporting capacity, and the interest of the local people. It emphasizes a lucrative collaboration among tourist, local people, and area of the tourism destination. This opposes to the traditional development tourism prioritizing difference and conflict of interest.

\section{REFERENCES}

[1] M. L. S. Jamil, Pariangan Mutiara yang Hilang. Padang Panjang: Mutiara Lestari, 2017.

[2] M. L. S. Jamil, Soempah Satie Marapalam Pondasi ABS SBK Di Minangkabau. Padang Panjang: CV Minang Lestari, 2018.

[3] F. Rangkuti, Analisis SWOT Teknik Membedah Kasus Bisnis. Jakarta: PT Gramedia Pustaka Utama, 1999.

[4] S. P.R, Strategi Pembangunan Kota Denpasar yang Berwawasan Budaya: Sebuah Bunga Rampai Lanjutan dalam Perspektif Sektoral. Denpasar: Bappeda Kita Denpasar, 2001.

[5] A. Ghazali, Bersufi Melalui Musik. Yogyakarta: Gama Media, 2003.

[6] D. P. dan Kebudayaan, Proyek Penerbitan dan Pencatatan Kebudayaan Sumatra West. Djakarta: Dekdikbud, 1971. 
[7] R. Amran, Sumatera West Plakat Panjang. Jakarta: Sinar Harapan, 1981.

[8] R. Amran, Sumatera West Hingga Plakat Panjang. Jakarta: Sinar Harapan, 1981.

[9] S. P. dan I. P. Warpani, Warpani.Pariwisata dalam Tata Ruang Wilayah. Bandung: Penerbit ITB, 2007.

[10] Khanizar, Membaca Seni Pertunjukan; Membingkai Etnoestetika. Padang: Andalas University Press, 2014

[11] Khanizar, "Genealogy Cultural Aesthetics Of The Sumatran West Coastal Community," Cult. Stud., vol. 9, no. 3, 2016.

[12] B. Udono, Sukses Menjadi Pemandu Wisata Profesional. Jakarta: Kesaint Blanc, 2008.

[13] P. Ricoeur, Teori Interpretasi: Memahami Teks, Penafsiran, dan Metodologinya. Yogyakarta: IRCiSoD, 2012.

[14] O. A. Yoeti, Ekonomi Pariwisata: Introduksi, Informasi, dan Implementasi. Jakarta: Kompas, 2008.

[15] I. W. Ardika and D. Putra, Politik Kebudayaan dan Identitas Etnik. Denpasar: Fakultas Sastra Universitas Udayana dan Balingmangsi Perss, 2004.

[16] K. Saddhono, "Cultural and social change of foreign students in Indonesia: The influence of Javanese Culture in Teaching Indonesian to Speakers of Other Languages (TISOL)." IOP Conf. Ser.: Ear. and Envi. Sci.. vol. 126 no. 1. IOP Publishing, 2018. 